Article

\title{
Research and Development Directions for Design Support Tools for Circular Building
}

\author{
Charlotte Cambier ${ }^{1, *}{ }^{\mathbb{D}}$, Waldo Galle ${ }^{1,2}$ and Niels De Temmerman ${ }^{1}$ \\ 1 Department of Architectural Engineering, Vrije Universiteit Brussel, 1050 Brussels, Belgium; \\ Waldo.Galle@vub.be (W.G.); Niels.De.Temmerman@vub.be (N.D.T.) \\ 2 Transition Platform, Flemish Institute for Technical Research (VITO), Boeretang 200, 2400 Mol, Belgium \\ * Correspondence: Charlotte.Cambier@vub.be; Tel.: +32-(0)2-629-1872
}

Received: 30 June 2020; Accepted: 12 August 2020; Published: 18 August 2020

\begin{abstract}
To support the construction sector in its transition to a circular economy, many design instruments and decision support tools have been and are still being developed. This development is uncoordinated and raises confusion among building designers and advising engineers, slowing down the tools' adoption in practice. Moreover, it is unclear if the available design tools are able to fulfil the needs of design professionals at all. Therefore, this research identifies the knowledge challenges for the "supply and demand" of design tools for a circular construction practice. It focuses on Flanders, given the importance the topic receives in the region's policy programme and among practitioners. This study builds on a thorough literature review, and on inventorying and categorising instruments and ongoing developments. By comparing that review with the needs that were identified during interviews with a focus group, it was possible to pinpoint designers' needs for support tools and outline three urgent research tracks. More generally, it was found that the needs of our focus group are only partially reflected by the available design tools and the ongoing developments. This identified mismatch advocates for a more participatory and practice-oriented research approach when developing design support tools for circular building.
\end{abstract}

Keywords: design for circularity; design support tools; circular construction; circular economy

\section{Introduction}

In recent years, a growing academic, political and industrial interest has been arising in transitioning from a linear to a circular economy (CE) [1,2]. A CE can be defined as "an economic system that is based on business models which replace the 'end-of-life' concept with reducing, alternatively reusing, recycling and recovering materials [...] with the aim to accomplish sustainable development [...].", according to Kirchherr et al. [3], who identified 114 different CE definitions.

The construction sector has an important role in the transition to a CE, as it accounts for about $50 \%$ of all extracted material and for over 35\% of the EU's total waste generation [4]. Therefore, the European Commission identified "construction and buildings" as one of the seven key product value chains in its Circular Economy Action Plan [4]. Also, subsequent Flemish Governments have set the transition of the construction sector to a circular economy as one of their priorities $[5,6]$.

Since 2014, the policy programme "Material-Aware Construction through Circular Supply Chains-A Sustainable Materials Management Prevention Program for the Construction Sector 2014-2020" [7] aims to establish an economy of closed material loops through socio-technical innovations in the Flemish construction sector [8]. The programme is governed by the Flemish Government's Agency for Public Waste, Materials and Soil (Openbare Vlaamse Afvalstoffenmaatschappij OVAM) under the auspices of the regional government of the Belgian region Flanders. As stated by Silva et al. [9], "the Flemish Sustainable Material Management program initiated by OVAM, was the first larger scale 
waste to materials policy restructure in the world, [ ... ] and won a Circular award at the World Economic Forum for its dedication to shift towards a circular economy". Paredis [10] explained earlier:

"All in all, the change in discourse from waste to sustainable materials management is undeniable. It is not only taken up in the Materials Decree and propagated by OVAM as main government actor, it also seems to find support with all actors involved in the waste/materials system: advisory councils, different sectors of the industry, knowledge actors, such as universities and VITO, and NGOs. Politically, the build-up of the discourse coalition benefited from the possibility to link it to ongoing developments at European level and to the innovation and green economy debate at Flemish level".

More recently, to accelerate the implementation of the Flemish policy programme and to increase its impact, sector-oriented initiatives were set-up to foster new demolition and design practices, for example, waste management organisations (e.g., Tracimat) and design instruments [11], or so-called green deals [12] and project calls [13].

When taking a broader look at the rather complex landscape of the circular economy, one can notice that multiple pathways and directions are taken in various regions [14]. Circular economy has become a political ambition in the European Union and other countries worldwide, such as China and Japan [2], where each country or region has its own focal points. Even with given direction from the EU [4] and international standards [15], variations among different continents and even among EU-member states can be noticed in various sectors, including in construction. Whereas, in Portugal, for example, the $\mathrm{CE}$ concept is mostly applied in the area of waste management, in countries like Belgium and The Netherlands they also emphasise the implementation of CE principles in the design stage.

This diversity and divergence was also identified by Bauwens et al. who posit "that a CE can be conceptualized in very different ways and that it is essential to better examine the trade-offs between these conceptual models and their societal consequences" [16]. This diversity is not uncommon for challenging sustainability transitions. Transition Management researchers Geels and Schot name these multidimension processes "co-evolution" or "co-construction" and argue that the conjuncture of multiple developments is important for any transition's success [17].

Given that Flanders can be considered as one of the forerunners in the transition towards a circular construction economy (with varying success), it makes the region and its ongoing initiatives a well-documented and instructive case for reflection and learning about the transition itself.

Furthermore, in addition to the different directions of CE, today, many innovative experiments are being performed and various collaborations are taking shape. Also, in Flanders, experimenting with CE principles and exchanging knowledge and experiences is encouraged by, amongst others, the Flemish transition hub Circular Flanders. As a result, applications and analytical studies are each taking their own approach, and different practitioners have to navigate the increasing "methodological noise" and try to make sense of the available information and means for their own working context.

Hence, the transition to a $\mathrm{CE}$ within the construction sector still faces major challenges. The transition implies radical changes at different levels and scales: from organisational changes within the sector to new building design methods $[14,18,19]$. Due to the numerous challenges and the rather complex landscape of the circular economy, and even though there is a demand from Belgian construction stakeholders to implement circular building concepts [20], the construction sector still struggles to effectively put circularity into practice. For example, building designers find it difficult to design circular construction products or buildings, when there is a lack of interest, knowledge, skills or incentives [21,22].

As an answer to the struggles of this specific stakeholder group (i.e., the building designers and advising engineers), the demand and supply of design support tools for circular building is rising [21-23]. Design support tools intend to facilitate the design process. They can be defined as instruments of any form or kind that address architects and/or advising engineers, include circular design principles and/or evaluation criteria, and aim to make better informed design choices. These tools 
can be an important enabler in the transition towards a circular building sector [24] through providing guidance on, for instance, waste generation, material selection, making reversible connections between building elements, and on the reuse and recycling potential [25]. However, when using existing design support tools for circular building, or before developing new ones, one should know which tools are available, what their effectiveness and limitations are, and which tools or features are still missing. Due to the lack of an overview of the available tools [20] and a comparative framework, it remains unclear for designers and advising engineers which tools fit their way of working and the context of their projects. Further, there is a lack of understanding of what designers need of (features in) design tools [20]. Addressing the needs of these stakeholders is crucial to understand the potential uptake of tools, and it lowers the risk of putting effort into developing new design support tools without answering any need [26].

The present study was set-up to classify available design support tools for circular building, to identify building designers' and advising engineers' needs and expectations from such tools, and to reveal which research tracks on design support tools for circular building are currently being developed. The tools as well as the needs were classified per building design aspect and by design stage. This way, the tools and the needs could be compared. Subsequently, conclusions could be drawn on the effectiveness and limitations of the available design support tools, on opportunities to improve available tools, and on prospects to develop new tools for circular building.

We assumed that guiding the practitioners through this experimental phase, with finding the tools and methods that support their specific situation best, can accelerate the learning and transition process, or at least make it as effective as possible.

\section{Method}

This study was done in five phases (Figure 1). The first phase entailed the selection and review of relevant design support tools for circular building. The design support tools were initially collected based on the authors' own knowledge of existence of such tools, enlisting other researchers and practitioners on their awareness and attending various events and presentations where design support tools were (partly) discussed. The relevant tools for this study were selected by using four criteria in line with the adopted definition mentioned earlier: instruments of any form or kind that address architects and/or advising engineers, include circular design principles and/or evaluation criteria and aim to make better informed design choices. The first selection criterium was "relevant for the Flemish building sector", related to the location context of this study, where tools were selected that are developed by Flemish or Dutch developers or by internationally known developers (e.g., The Ellen MacArthur Foundation, the European Commission and Pré (SimaPro)). The second selection criterium was "(claim to) support circular building". The tools were screened on the adoption of the circular design principles "closed-material loops" and "life cycle design". The third selection criterium was "available for use". Only tools which were ready for immediate use were selected. Tools that were still in the research phase or in the development were eliminated. The fourth and last criterium was that they should "address building designers and advising engineers". For example, written documents without a coupled action were considered redundant for this stakeholder group, and 38 tools remained after the selection process.

The process of categorising the tools was similar to defining themes in transcribed interviews [27]. A predetermined list of categories was set-up before defining the categories of the selected tools. This list contained general categories such as assessment tools, principle tools, economic tools and describing tools. This list was subsequently complemented during the review of their role in the design process. The six resulting categories were: Circular design strategies, Circularity score, Environmental impact, Product and material choice, Practical examples and Circular business models. 


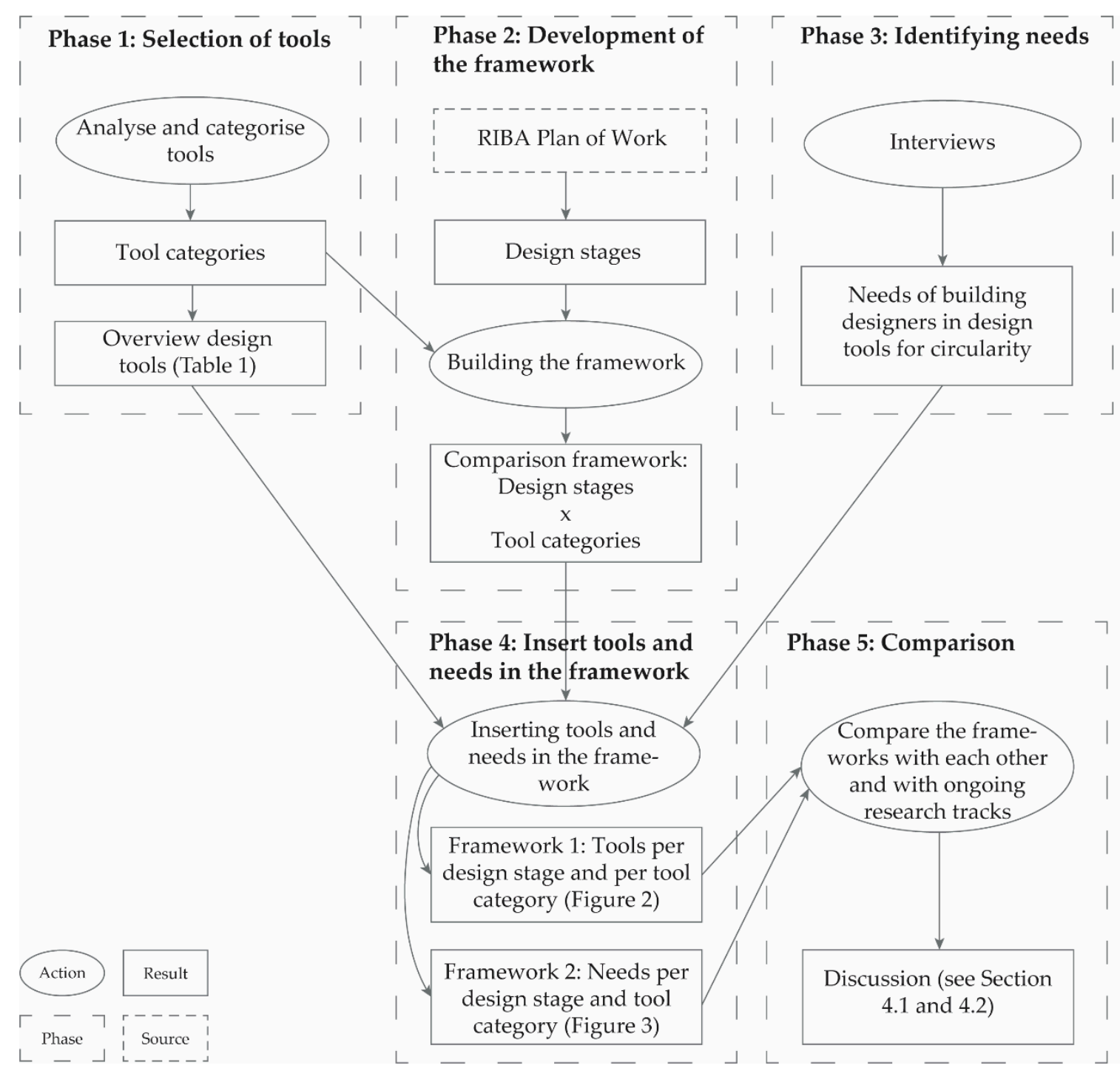

Figure 1. Diagram that shows the actions and results of the five research phases. RIBA is the Royal Institute of British Architects.

In the second phase, a framework that allows the consistent mapping of tools and needs was set-up. On the horizontal axis of the framework different building design stages were listed. Those stages were based on the Royal Institute of British Architects' (RIBA) Plan of Work [10] which is the definitive UK model for the building design and construction process and which was translated and verified for Flanders by Lespagnard [28]. On the vertical axis, the identified and abovementioned design tool categories were lined up.

During the third phase, stakeholders were interrogated through face-to-face, semi-structured interviews. The aim of the interviews was to obtain a preliminary but thorough idea of what the needs were of building designers concerning design support tools for circular building. Through in-depth individual interviews, valuable information could be provided on the personal thoughts and perspectives of the stakeholders on these needs. Seven interviews were conducted with different interviewees: a researcher on sustainable buildings (15 January 2019, Heerlen, The Netherlands), a facade contractor/designer (21 January 2019, Velp, The Netherlands), an architect (22 January 2019, Antwerp, Belgium), a sustainability engineer (23 January 2019, Louvain-la-Neuve, Belgium), an architect (03 September 2019, Antwerp, Belgium), an architect (04 November 2019, Brussels, Belgium) and an architect (06 November 2019, Brussels, Belgium). The interviewees were Flemish or Dutch 
forerunners active in Flanders and were selected by the researchers on the basis of their familiarity with circular design principles and their practical design experience. This was assessed by reviewing their portfolio and their explicit circularity ambitions in various media. Although not representative for the whole sector, working with forerunners, as advised by Geels et al. [29], was important to have an in-depth understanding of the needs in design support tools for the still uncommon but generally envisioned practice of circular building. Concretely, interviewees were asked about their perceived needs and motivations related to the abovementioned tool categories in order to be able to proceed in designing circular buildings. The interview guide is available in Appendix A.

The fourth phase consisted of filling out the developed framework twice: once with the identified needs and once with the reviewed tools. To determine to which design phase(s) the tools belonged, three questions of the RIBA Plan of Work were adopted:

1. For the feasibility design phase: does the tool assist in making design decisions on project objectives, sustainability aspirations, concept design or programme?

2. For the developed design phase: does the tool assist in making design decisions on the proposals for structural design, building services systems, outline specifications, cost information or project strategies?

3. For the detailed design phase: does the tool assist in making design decisions on the coordinated and updated architectural, structural and building services proposals? Is material and dimension-specific information needed to do the calculations?

During the fifth and last phase, the two filled-out frameworks were compared with each other. The similarities and mismatches among the tools and the needs were identified, reviewed and analysed. Additionally, the ongoing main research and development tracks on the development of design support tools for circular building design were outlined. These research paths were also compared with the needs of the building designers and advising engineers. Last, further research and development paths were identified and proposed for practitioners, tool developers and researchers, based on a synthesis of the previous phases.

\section{Results}

\subsection{Existing Design Support Tools for Circularity}

The 38 tools that met the four set criteria are listed in Table 1 . They were inventoried during the period October 2019-April 2020. It should be noted that the list is not exhaustive, and other tools may exist, as tools and their features can change rapidly in this field. 
Table 1. Non-exhaustive list of design support tools for circular building in alphabetical order.

\begin{tabular}{|c|c|c|c|c|}
\hline Tool & Developer & Publisher & Year Published & Source \\
\hline $\begin{array}{c}16 \text { Design Qualities for a } \\
\text { Circular Economy (Design } \\
\text { principles ((DP)) }\end{array}$ & $\begin{array}{l}\text { Vrije Universiteit Brussel } \\
\text { (VUB) Architectural } \\
\text { Engineering }\end{array}$ & $\begin{array}{c}\text { Le Bati Bruxellois Source } \\
\text { de Nouveaux Materiaux } \\
\text { (BBSM) Research } \\
\text { Consortium }\end{array}$ & 2019 & [30] \\
\hline $\begin{array}{l}24 \text { Design Principles for } \\
\text { Design for Change (DP) }\end{array}$ & $\begin{array}{c}\text { VUB Architectural } \\
\text { Engineering, Vlaamse } \\
\text { Instelling voor } \\
\text { Technologisch Onderzoek } \\
\text { (VITO) and KULeuven }\end{array}$ & $\begin{array}{c}\text { Openbare Vlaamse } \\
\text { AfvalstoffenMaatschappij } \\
\text { (OVAM) }\end{array}$ & 2016 & [31] \\
\hline $\begin{array}{l}\text { Business Model } \\
\text { Innovation Grid }\end{array}$ & $\begin{array}{c}\text { Nancy Bocken, Samuel } \\
\text { Short, Padmakshi Rana } \\
\text { and Steve Evans } \\
\text { (University of Cambridge) }\end{array}$ & Circular Flanders & - & [32] \\
\hline $\begin{array}{l}\text { Bouwcatalogus } \\
\text { Veranderingsgericht } \\
\text { Bouwen (DP) }\end{array}$ & $\begin{array}{c}\text { Vlaams Instituut voor } \\
\text { Bio-ecologisch Bouwen en } \\
\text { Wonen (VIBE) }\end{array}$ & OVAM & 2019 & [33] \\
\hline Building Circularity Index & $\begin{array}{l}\text { Alba Concepts, Verberne } \\
\text { Jeroen (TU Eindhoven) }\end{array}$ & Alba Concepts & - & [34] \\
\hline C-calc & Cenergie & Cenergie & 2018 & [35] \\
\hline $\begin{array}{c}\text { Circular Building } \\
\text { Assessment Prototype }\end{array}$ & $\begin{array}{l}\text { Building Research } \\
\text { Establishment (BRE), } \\
\text { VITO, University of } \\
\text { Twente }\end{array}$ & $\begin{array}{l}\text { Buildings As Material } \\
\text { Banks (BAMB) Research } \\
\text { Consortium }\end{array}$ & 2018 & [36] \\
\hline Circular Design Guide & $\begin{array}{l}\text { The Ellen McArthur } \\
\text { Foundation and Ideo }\end{array}$ & $\begin{array}{l}\text { The Ellen McArthur } \\
\text { Foundation }\end{array}$ & 2018 & [37] \\
\hline $\begin{array}{l}\text { Circular Transition } \\
\text { Indicators }\end{array}$ & $\begin{array}{l}\text { World Business CouncilFor } \\
\text { SustainableDevelopment }\end{array}$ & Circular IQ & - & [38] \\
\hline Circularity Calculator & IDEAL and CO Explore BV & IDEAL and CO Explore BV & 2017 & [39] \\
\hline Circulator & $\begin{array}{l}\text { VITO, Circular Flanders, } \\
\text { TU Delft, Rasboud } \\
\text { University }\end{array}$ & EIT RawMaterials & - & [40] \\
\hline Circulytics & $\begin{array}{l}\text { The Ellen McArthur } \\
\text { Foundation }\end{array}$ & $\begin{array}{l}\text { The Ellen McArthur } \\
\text { Foundation }\end{array}$ & - & [41] \\
\hline $\begin{array}{l}\text { Closing the Loop by } \\
\text { Design }\end{array}$ & UTwente & Remeha BV & 2018 & [42] \\
\hline Ecolizer Ontwerptool & OVAM, VITO & OVAM & 2011 & [43] \\
\hline $\begin{array}{l}\text { Green Deal Circulair } \\
\text { Bouwen (Platform) }\end{array}$ & $\begin{array}{c}\text { Circular Flanders, OVAM, } \\
\text { Vlaamse Confederatie } \\
\text { Bouw }\end{array}$ & Circular Flanders & 2019 & [12] \\
\hline $\begin{array}{c}\text { GaBi Circularity Toolkit } \\
\text { (Life Cycle Assessment } \\
\text { (LCA)) }\end{array}$ & Sphera & Sphera & - & [44] \\
\hline GRO & Het Facilitair Bedrijf & Het Facilitair Bedrijf & 2020 & [45] \\
\hline $\begin{array}{l}\text { Harvestmap/OogStkaart } \\
\text { (Reused Materials (RM)) }\end{array}$ & Superuse Studios & Superuse Studios & - & [46] \\
\hline IMPACT (LCA) & BRE Group & BRE Group & - & [47] \\
\hline Insert Marktplaats (RM) & Insert, Buro Boot & Insert & - & [48] \\
\hline Kernmeetmethoe & $\begin{array}{l}\text { Action team }(36 \\
\text { participants) }\end{array}$ & Platform CB'23 & 2020 & [49] \\
\hline Level(s) & $\begin{array}{l}\text { European Commission } \\
\text { Joint Research Centre }\end{array}$ & EuropeanCommission & 2020 & [50] \\
\hline $\begin{array}{c}\text { Madaster platform } \\
\text { (Materials Passport (MP)) }\end{array}$ & Madaster Services & Madaster Services & - & [51] \\
\hline
\end{tabular}


Table 1. Cont.

\begin{tabular}{|c|c|c|c|c|}
\hline Tool & Developer & Publisher & Year Published & Source \\
\hline MarketplaceHUB (RM) & $\begin{array}{l}\text { World Business Council for } \\
\text { Sustainable Development }\end{array}$ & $\begin{array}{l}\text { World Business Council for } \\
\text { Sustainable Development }\end{array}$ & - & [52] \\
\hline $\begin{array}{l}\text { Material EIA for } \\
\text { Single-Family Dwellings }\end{array}$ & Elke Meex et al. & UHasselt & 2019 & [53] \\
\hline $\begin{array}{l}\text { Milieuclassificaties } \\
\text { Bouwproducten }\end{array}$ & $\begin{array}{l}\text { Nederlands Instituut voor } \\
\text { Bouwbiologie en Ecologie } \\
\text { (NIBE) }\end{array}$ & NIBE & 2019 & [54] \\
\hline $\begin{array}{c}\text { Online Material Flow } \\
\text { Analysis Tool (Material } \\
\text { Flow Analysis (MFA)) }\end{array}$ & Team Metabolism Of Cities & Metabolism Of Cities & 2020 & [55] \\
\hline One Click LCA (LCA) & Bionova Ltd. & Bionova Ltd. & - & [56] \\
\hline Opalis (RM) & Rotor vzw, Atelier $4 \mid 5$ & Rotor vzw & - & [57] \\
\hline OpenLCA (LCA) & GreenDelta & GreenDelta & - & [58] \\
\hline Platform CB'23 (Platform) & 13 companies & $\begin{array}{c}\text { Circulair Bouwen } 2023 \\
\text { (CB'23) }\end{array}$ & 2018-2023 & [59] \\
\hline Pixii (Platform) & Pixii & Pixii & - & [60] \\
\hline ReCiPe method (LCA) & $\begin{array}{c}\text { Rijksinstituut voor } \\
\text { Volksgezondheid en Milieu } \\
\text { (RIVM), Radboud University } \\
\text { Nijmegen, Leiden University, } \\
\text { PRé Sustainability }\end{array}$ & $\begin{array}{l}\text { Dutch National Institute } \\
\text { for Public Healthand the } \\
\text { Environment }\end{array}$ & 2018 & [61] \\
\hline $\begin{array}{l}\text { Scenario based Life Cycle } \\
\text { Costing (LCC) }\end{array}$ & Waldo Galle et al. & $\begin{array}{l}\text { VUB Architectural } \\
\text { Engineering }\end{array}$ & 2016 & [62] \\
\hline SimaPro (LCA) & PRé Sustainability & PRé Consultants BV & - & [63] \\
\hline Stan (MFA) & $\begin{array}{l}\text { TU Wien, Institute for Water } \\
\text { Quality, Resource and Waste } \\
\text { Management }\end{array}$ & $\begin{array}{c}\text { TU Wien, Institute for } \\
\text { Water Quality, Resource } \\
\text { and Waste Management }\end{array}$ & 2012 & [64] \\
\hline Totem & $\begin{array}{c}\text { VITO/EnergyVille, KU } \\
\text { Leuven, Wetenschappelijk } \\
\text { en Technisch Centrum Voor } \\
\text { Het Bouwbedrijf (WTCB) }\end{array}$ & $\begin{array}{l}\text { OVAM, Brussels } \\
\text { Environment, Wallonie } \\
\text { Service Public }\end{array}$ & 2020 & [65] \\
\hline Werflink (RM) & Floow2 & Werflink & - & [66] \\
\hline
\end{tabular}

When the available design support tools from Table 1 are situated in the developed framework and sorted per design phase and per design tool category (Figure 2), it becomes clear that some tools serve the same purpose and can be clustered. As Figure 2 shows, this results in eight subcategories of tools (darker coloured bars), in addition to 17 more unique tools (light coloured bars). Although the exact impact and role of each tool might vary from project to project, depending on the adoption by its users, the similarity among the majority of tools raises questions about the tools' effective complementarity in terms of goal and scope. 


\begin{tabular}{|c|c|c|c|}
\hline Categories & Feasibility design phase & Developed design phase & Detailed design phase \\
\hline \multirow{3}{*}{$\begin{array}{r}\text { Circular } \\
\text { Design } \\
\text { Strategies }\end{array}$} & \multicolumn{2}{|c|}{ Circular design principles tools (DP) } & \\
\hline & Circular Design Guide & & \\
\hline & Scenario planning technique & & \\
\hline \multirow{9}{*}{$\begin{array}{r}\text { Circularity } \\
\text { Score }\end{array}$} & Circularity Calculator & & \\
\hline & Kernmeetmethode & & \\
\hline & GRO & & \\
\hline & Building Circularity Index & & \\
\hline & Circulytics & & \\
\hline & & Circular Building Assessment & \\
\hline & & C-CalC & \\
\hline & & Level(s) & \\
\hline & & Circular Transition Indicators & \\
\hline \multirow{3}{*}{$\begin{array}{r}\text { Environmental } \\
\text { impact }\end{array}$} & Totem & & \\
\hline & \multicolumn{2}{|c|}{ Material Flow Analysis tools (MFA) } & \\
\hline & & Life Cycle Assessment tools (L & \\
\hline
\end{tabular}

Product and Ecolizer

material choice Material EIA for single-family dwellings

Environmental classifications of construction materials Material and Product Labels

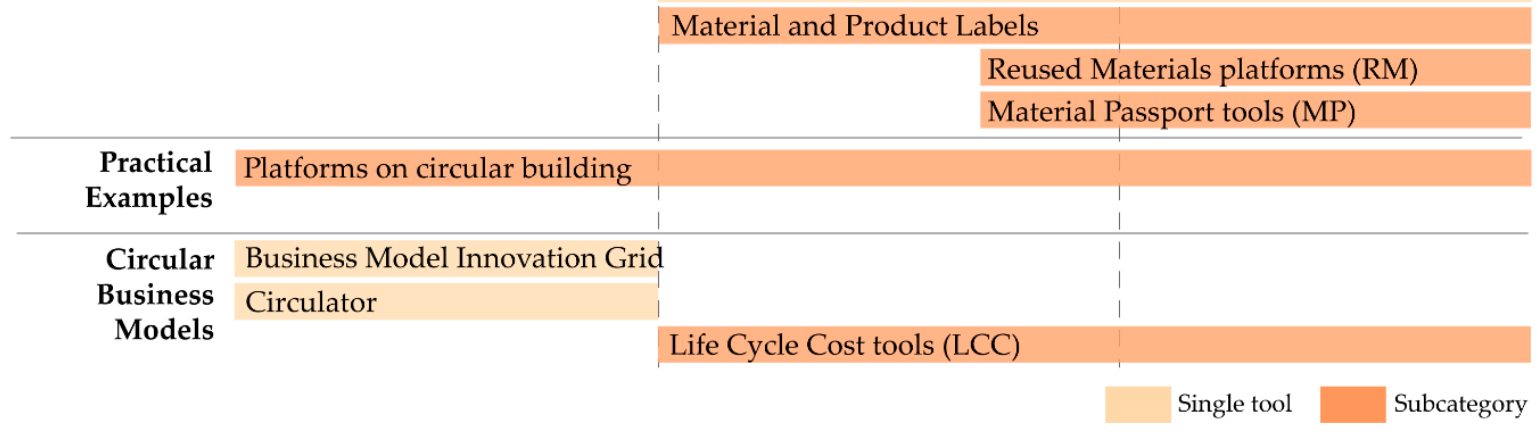

Figure 2. Framework 1: Categorisation of the design support tools for circular building per design phase and per design tool category. Tools that serve the same purpose and have the same target audience are further clustered in subcategories (darker bars).

From the review and the filled-out framework, a series of findings becomes apparent. They can be discussed per design tool category:

- Circular Design Strategies: A circular design strategy tool, such as the "Circular Design Guide" of The Ellen McArthur Foundation, aims to offer guidance in considering alternative design decisions through design strategies. One subcategory was identified: the Circular Design principle tools (DP), containing tools that have a number of principles, strategies or qualities that can be set as ambitions but which are not linked to a scoring system. For example, the "Design Qualities" (VUB Architectural Engineering) presents 16 circular design considerations linked to different design strategies and circularity principles, and "Closing the Loop by Design" (Remeha B.V.) presents 36 guidelines in four different categories (architecture, component, connection, and material).

- Circularity score: Circularity scoring tools aim to objectify the circularity performance of a building or a building element through a scoring or assessment system. A scoring system often forms the basis for comparative analysis [24]. There are various attempts to develop a tool that calculates or measures the level of circularity of a building. The way circularity is evaluated and scored still differs largely from one tool to another. For example, C-Calc (Cenergie) evaluates on three aspects which are equally weighted in all projects: material use, adaptability and information flow, while GRO (Het Facilitair Bedrijf) takes into account 29 design aspects and also considers the 
level of ambitions and project-specific information. This issue is further tackled in the discussion section below.

- Environmental impact: Life cycle assessment (LCA) and material flow analysis (MFA) are well-known methods for assessing the environmental impact on the built environment, and they are suitable for analysing the environmental performance of circular systems and designs [67-69]. For each of these methods, several tools were developed (Table 1) and which are translated into subcategories LCA and MFA (Figure 2). The Totem tool focusses on the Belgian construction sector and aims to measure the environmental effect of building elements through 17 environmental impact indicators. The scores of each indicator are expressed per $\mathrm{kg} \mathrm{CO}_{2}$ eq. for global warming [70]. The developer's intend to further develop the tool with regard to the circular design aspect.

- Product and material choice: This tool category includes design support tools that focus on the building product and material level. For example, NIBE developed the "Environmental classification of building materials and products". Furthermore, the subcategory "Material and Products Labels" can be seen as a scoring system at the material and product level. Before the label is obtained, some (environmental and perhaps circular) criteria must be met which is thoroughly checked by an independent inspection body [71].

- Practical examples: Practical examples, such as technical details and case studies, can be of great value when working out a circular construction project. There are several platforms that try to gather knowledge and such examples in one central place, gathered in the subcategory "Platforms on Circular Building". The collected knowledge and information are usually shared partly online and partly through events and workshops. Moreover, it is frequently the intention to link partners concerning circular building and do matchmaking. In Flanders, the most common platform concerning circular building is the Green Deal Circular Building platform.

- Circular business models: The linear model of "take, make and dispose" has reached its limits. Also, the fragmented supply chain in the construction sector is a key challenge in the transition towards a circular economy [21]. A number of tools have been developed to help realise this transition in terms of the business model such as the Business model innovation grid (Circular Flanders) and Circulator (EIT RawMaterials). The subcategory "Life Cycle Costing Tools" (LCC) includes tools that study long-term costs and revenues and can calculate the financial consequences of applying circular business models or circular principles [62].

\subsection{Building Stakeholders' Needs for Design Support Tools}

Having categorised the design tools, the question is whether or not they answer the needs of the building designers and advising engineers who are trying to integrate circular principles in their practice. Therefore, the needs that are expressed by our focus group are placed in the developed framework, where they are categorised per design stage and per circular design tool category (Figure 3).

For a consistent categorisation of the expressed needs, the specific role of architects and advising engineers in Flanders was taken into account. That role is broader than "designing plans" and, thus, different from some other regions. Architects and advising engineers in Flanders are a pivotal figure between the client and contractors, they are obliged to supervise the construction works and remain responsible 10 years after completion of the building. Moreover, regulations require architects to implement increasingly more diverse knowledge on specific themes such as energy and water use or building safety and health. They are also expected to have insight into the society, whereby they have the ability to respond to future needs of building users and to be informed of the latest (innovative) building trends and solutions. The emergence of the circular economy in construction is consequently considered as "yet another constraint" by multiple designers [72]. 
Categories Feasibility design phase

Developed design phase

Detailed design phase

Circular Strategies and procedures to guide and enhance design for circularity (4)

Design Circularity principles should be outlined per building element (6)

Strategies

General principles on circular design or general information on CE $(3,5)$

Tool to rate the adaptability or reversibility (7)

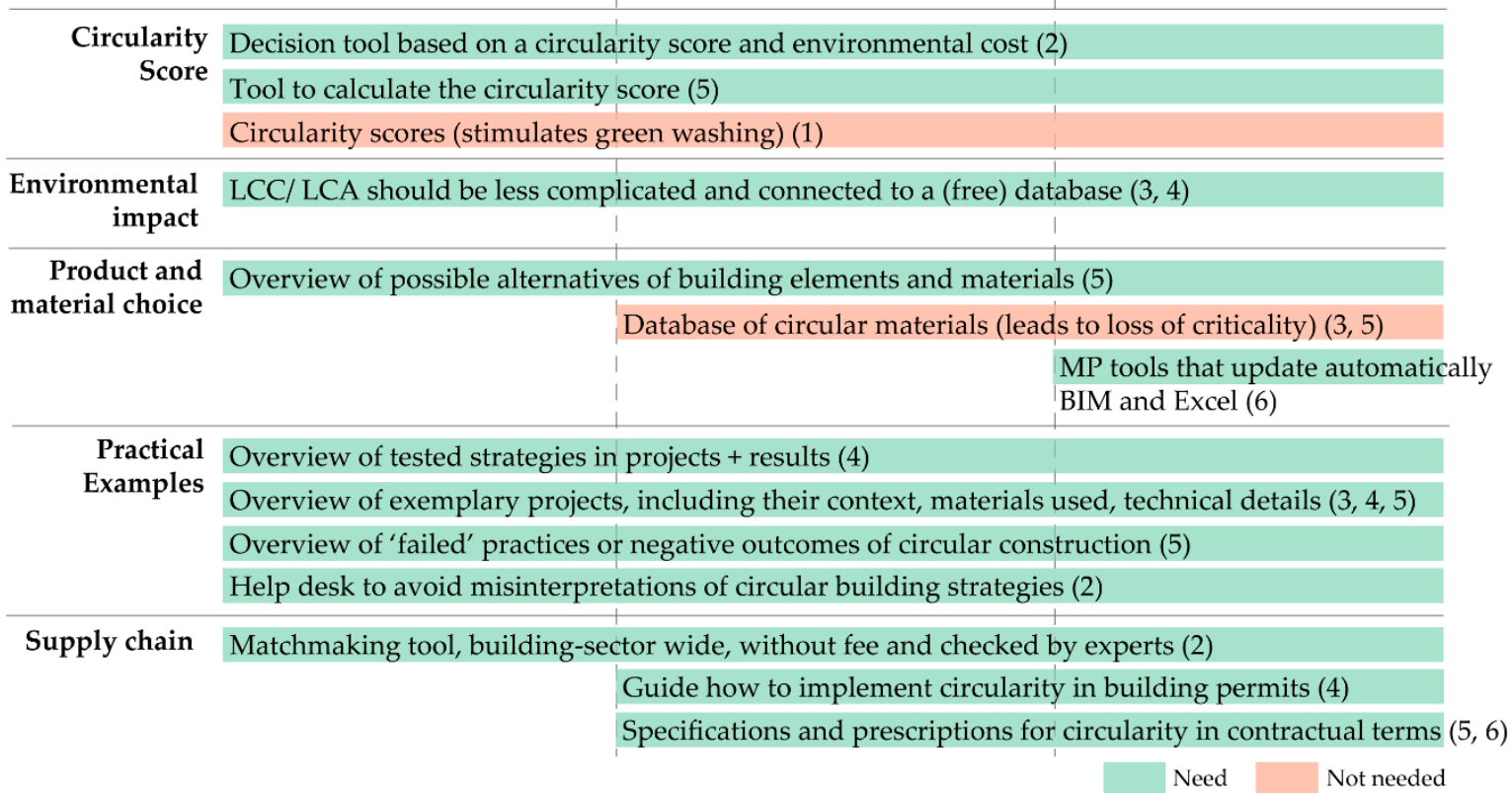

Figure 3. Framework 2: Categorisation of the building designers' and advising engineers' needs for tools for circular building per design phase and per design tool category (green bars). Related interviews are indicated as: (1) researcher sustainable buildings; (2) facade contractor/designer; (3) architect (engineering office); (4) sustainability engineer; (5) architects; (6) architect; (7) architect.

From the interviews and the filled-out framework, a series of findings becomes apparent. They can be discussed per design tool category:

- Circular design strategies: Multiple interviewees expressed that general guidelines or principles on circular building are sufficiently available during information sessions and in literature. However, it has emerged from Interview 6 that principles or guidelines that focus on specific building elements would be useful too but are lacking, for example, a guide that explains how to apply general principles to the facade.

- Circularity score: The need for a circularity score, expressed by the interviewees, shows a demand for some sort of measurability and straightforward evaluation of the level of circularity of a building project, resembling sustainability assessment tools, such as the Building Research Establishment Environmental Assessment Method (BREEAM) and Leadership in Energy and Environmental Design (LEED), which are widely used in Flanders. Some interviewees expressed that a scoring tool is not useful in the context of circular building. These observations are further discussed in Section 4.1. below.

- Environmental impact: Life cycle assessment and costing are considered time-consuming and complex to base design choices on. Moreover, some interviewees complained that (much of) the necessary data are not free of charge in order to perform a proper LCA. Hence, building actors demand less complex and more affordable methods to perform an environmental or financial impact analysis.

- Product and material choice: There is no unified opinion among the interviewees on whether certain building products or materials should be classified in a kind of "circular materials/product" database. Such a database's advantage could be a clear overview that allows to work faster and 
more informed. Conversely, the disadvantages include the risk that actors lose their criticality on materials and the difficulty to keep the overviews up to date in this transitioning sector.

- Practical examples: There is a much louder call for overviews of projects where circular principles are already applied - this resonates with the need for more specific design strategies mentioned above. In such overviews, the outcomes and lessons could be structured and shared in a coherent way, according to the interviewees. This finding is consistent with the conclusion of Thelen et al. [73], where the lack of demonstration projects is mentioned as a barrier to the transition towards a circular economy. Moreover, the interviewees emphasize that failed practices must be shared too. While successful practices cannot seem to be shared fast enough, less successful experiments are seldomly shared [74]. As a result, today, there is still a lot of insecurity about the positive and negative outcomes of circular building strategies [75]. Therefore, showing the result of "failed practices" would be useful as learning opportunities towards more circular buildings, both economically and technically [76,77]. In the context of, for example, learning networks, not sharing the "failed practices" holds the risk that stakeholders will repeat the made mistakes rather than learning from them. The social conditions should be that people feel safe and joint responsibility is taken for failure, rather than attempting to find a scapegoat, as we tend to remember failure more and longer than success.

- Supply chain: Finally, the need was identified for clear management and monitoring tools to transfer information between partners in an efficient way, taking into consideration the growing complexity of the design process [20]. Linked to that, also matchmaking tools, to connect stakeholders with each other, are demanded. One interviewee stated that in a matchmaking tool, different than in platforms, the professionality of the participants should be verified [76]. Apart from the technical support from tools, there is a need for legal support too: some interviewees mentioned, for example, the need for guidance preparing building permit applications and contracts in line with circular design strategies (e.g., reuse of reclaimed components) or circular business models (e.g., as-a-service contracts).

\section{Discussion}

Comparing the available tools (see Section 3.1) and the building actors' needs (see Section 3.2) yields three possible outcomes: (1) there is a need but a corresponding tool is not (yet) available; (2) there is a need and a tool is available; and (3) there is no need, however, a tool is available. Each of these three situations is discussed hereunder and can be related to one or more tool (sub)categories and their role in the design process. Those situations are subsequently put in contrast with ongoing research tracks and developments.

\subsection{Comparing the Available Tools and the Building Actors' Needs}

First, from the interviews it can be concluded that there is an important need for practical examples and best practices. The current platforms and learning networks do not seem sufficient to bring those examples and best practices together and share them further. Although platforms enable information exchange and direct interactions [26], each has its flaws with regard to a scale-up of circular building. Some for example, accept only a small "expert" group, require a financial contribution, or lack a coherent structure [76]. Further, interviewees expressed an absence of practical examples with sufficient technical information [78], learned lessons, etc. Others repeat their demand for cases that did tackle and report on juridical challenges of circular building in today's context $[75,76,79]$. Moreover, platforms and learning networks do not, or only in one direction, facilitate matchmaking between professional partners interested in circular building. The coverage, usefulness and effect of platforms as they are today must therefore be questioned.

Second, during the interviews, needs were identified while tools are already available. Possible explanations for tools not being used are: marketing strategies are lacking, they are not satisfying the users' expectations or they are too complex, time-consuming, and expensive [80]. The ease of use, next to 
the associated costs, is one of the most important criteria when selecting design supporting tools [20]. User-friendliness of tools could include, for instance, compatibility with other software and compliance with standards and regulations [20]. This results in the dismissal of some tools, the remaining need for such tools and the oversupply of certain other tools. For example, this research identifies a need from practitioners for tools to calculate a circularity score, while there are already tools available that could (partly) do that. However, not all interviewees agree on the necessity and relevance of circularity scoring. Various possible disadvantages were mentioned: first, the term "circularity" could be greenwashed, i.e., a scoring tool that does not lead to more circular outcomes and falsely promotes its efforts (strategies, method and goals) as environmentally friendly or circular [81]. This means that a scoring tool can, for instance, focus on achieving certain circularity goals, such as using Building Information Modeling (BIM) to manage your project or designing the building elements in such a way that they could be reused after the building's lifespan, but does not necessarily serve the general goal of lowering the environmental footprint of the constructing sector. For this reason, vigilance and a critical eye are important to ensure a relevant implementation. That the terms "circularity" and "circular economy" are ambiguous and the broader socio-economic implications of a CE are often side-stepped [82] is extensively described in the growing literature that is analysing the CE and its problematic relationship with perceptions, policy and consumption such as by Hobson and Lynch [82], Gregson et al. [83], Torelli et al. [84] and Testa et al. [85]. Second, each project is different which makes it difficult to quantitatively measure indicators and to compare them as such. Until today, there is no agreed framework for circular building benchmarking. This means that the results generated by circularity score tools might differ significantly from each other, which could lead to confusion or misinterpretation. Developers of circularity score tools should thus be careful which indicators they measure and how they can avoid greenwashing and stimulate circular building. The different opinions on circularity scoring tools show that the needs are dependent per user and their expertise. However, in order to make any further conclusions, more research is needed on this topic.

Third, there is an oversupply of certain tools that are developed with the same purpose, for the same design phase, for the same design aspect and usually also for the same target group. On the one hand, this oversupply is represented by the eight subcategories of tools in Figure 3 and, on the other, by the red "Not Needed" bars in Figure 3. For example, the subcategory "Design Principle Tools" contains four tools available in Flanders. Two interviewees expressed that there was no need for more such tools that elaborate on theoretical principles of circular design. When developing a new tool concerning circular design principles, the added value of that tool should therefore be questioned and doing a focused survey on the remaining needs for information and guidance in design principles of circular construction is thus recommended.

\subsection{Ongoing Research Tracks and Developments on Design Support Tools for Circular Building}

Next to the available tools, there are ongoing research tracks on the development of design support tools for circular building design. These trends show that the circular economy still has a significant traction in academia and in the building practice. Most developments are focusing on (1) the integration of BIM with LCA; (2) the integration of BIM with circular design strategies; and (3) developing tools to measure circularity in a building. In this study, BIM was not seen as a design support tool as such but as a concept and method to enhance creating and managing information of a construction project by its linked database of geometric and nongeometric data attached to building elements. The main reason to integrate BIM with design support tools is to deliver accurate and adequate information of the building design, to decrease the (calculation) effort and to speed up the project process $[86,87]$. Additionally, in Belgium, $29 \%$ of the architect officesalready used BIM in their projects and $67 \%$ are aware of its functionalities in design practice [88]. This awareness could lead to a large implementation percentage of tools linked to BIM.

The first research track, the integration of BIM in LCA, has been progressively published in scientific literature in the last five years and new tools have been developed $[86,89,90]$. Building information 
modelling tools can facilitate quantitative assessments of design options, with automated inventories of material flows and waste [24,91]. This trend answers to the need of making LCA user friendlier (Figure 3). This is an important aspect, as ease of use is considered essential (85\%), even more than the cost of a tool (63\%) according to a survey done with 224 Flemish architects [20].

Similarly, the second research track concerns circular design strategies tools that become increasingly BIM compliant. For example, the disassembly network analysis method uses BIM and network analysis to analyse the interdependency between building elements to define which elements are recovered and lost during the disassembly of a building and to calculate how long the disassembly takes [91]. Other examples are the BIM-Based Deconstructability Assessment Score, which determines the extent to which a building could be deconstructed [24], and the disassembly planning method of Sanchez et al. [92]. Integrating BIM in design tools for reversible buildings is a result of the support that BIM can offer in this respect: efficiently developing three-dimensional representations of a reversible building, identifying spatial conflicts in the design and collaboratively resolving them with clash detection software [93].

A third development path contains tools and methods that aspire to quantify circularity in buildings. They do so in two different ways. First, the research on circularity indicators in construction is growing [94-96]. For example, Verberne et al. [95] developed a tool that determines the degree of circularity. However, also in this case, the comment was made that the assessment model is meant to provide guidance in concretising the ambitions and should not be seen as an absolute outcome. In the same vein, Flanders developed the GRO tool which is based on sustainability criteria and performance levels [45]. Second, adaptive capacity quantification tools arise as well [97]. For example, the Spatial Assessment of Generality and Adaptability (SAGA) method uses weighted graphs to quantify a building's capacity to support changes [98], the FLEX 4.0 uses a point-based system to assess the adaptive capacity of buildings [99], and the AdaptSTAR model is based on a weighted checklist scoring system to evaluate future adaptation potential in newly designed buildings [100].

Next to those three main research tracks, there are also several tools that do not fit a well-developed research track. There are some initiatives to develop collaboration tools for circular economy in the building sector that is published in the scientific literature such as by Leising et al. [101] and Simons et al. [102]. The conceptual tool "Circular Building Components"-generator aims to support designers in creating and reviewing circular design options [103]. Furthermore, when looking at a broader perspective than the construction sector, more tools on circular design are being researched and developed. For example, the tool of Gehin et al. [104] on implementing sustainable end-of-life strategies in the product development phase, the value mapping tool for sustainable business modelling by Bocken et al. [105], the Circular Material Library of Virtanen et al. [106] and the assessment tool for end of life product recovery strategies by Alamerew et al. [107] are studies aiming to develop design support tools for all kinds of circular products.

\subsection{The Relevance of Design Tools}

In the busy and increasingly complex practice of building designers, the question is to what extent tools are picked up and used to steer design choices. In general, design practice is largely based on experience and less on tools. This statement is confirmed by the survey of Weytjens et al. [20]. They concluded that design decisions are mainly based on experience, the client's demands and on regulations. Intuition and reference projects are taken into account by over $35 \%$ of the respondents when making design decisions, whereas only $21 \%$ use design decision tools as a deciding factor [20]. This does, however, not mean that tools do not have an unconscious impact on the considered alternatives and course of the design process.

Similarly, the development and use of design support tools cannot only guarantee the creation of circular buildings. Several other enablers and barriers that have an influence on the transition to a circular economy in the construction sector have been outlined too [21,22,108,109]. Furthermore, users and 
developers must be aware about every project's specific context [2,14] and the broad scope every design process entails.

\section{Conclusions}

The present study was set-up to classify available design support tools for circular building, to identify building actors' needs and expectations from such tools and to reveal which research tracks on design support tools for circular building are currently being developed. This section divides the conclusions drawn and the actions to be taken for three types of actors: practitioners (building designers and advising engineers), tool developers and researchers.

First, from a practitioner's perspective, the present study categorises available design support tools for circular building and identifies designers' needs for such tools. This way, it offers an overview and reference to building designers and advising engineers which tools fit their particular needs, their way of working and the context of their projects(?), accelerating the tools' purposeful adoption in practice. Concretely, this study resulted in eight subcategories of tools each having its specific added value during different design stages: Design principles tools, Material flow analysis tools, Life cycle assessment tools, Material and product labels, Reused material platforms, Material passport tools, Life cycle cost tools and Knowledge sharing platforms.

Second, from a developer's perspective, this study reveals opportunities to work on new design support tools, to improve the already available tools and further accelerate their adoption. By comparing the identified needs through the set-up framework with ongoing developments on design support tools for circular building, it became clear that the needs of designers are only partially reflected by the available design support tools and the ongoing developments, and it is now better understood which features are overrepresented and which needs have received little attention so far. When developers create additional design support tools, they should investigate the tools already available, the support base of potential users and the added value of their tool. The resulting research agenda therefore includes these recommendations:

1. There is an oversupply of tools that illustrate the basic principles of circular building. In contrast, there is a loud call for a structured and detailed overview of practical examples and best practices on circular building. The current platforms and learning networks do not seem sufficient to bring those practical insights effectively together and share them further;

2. There is a need for clear workflow management and monitoring tools to transfer the information between partners in a more efficient way. Beyond sharing information, providing new insights and allowing better informed design choices by individual stakeholders, interviewees have put clear importance on collaboration from the start of a project;

3. Research tracks on design tools for circular building are mainly focused on the integration of BIM in LCA, on the integration of BIM in circular design strategies and on quantifying circularity in buildings. On the one hand, this is not in line with the practices and needs of designers to use this kind of integration as a design support tool. On the other hand, in Belgium, $29 \%$ of the architecture practices have already used BIM in their projects, and $67 \%$ are aware of its functionalities in the design practice [88]. This awareness could lead to a large implementation percentage of tools linked to BIM;

4. Not only development but also guidance in the use of design support tools are of high importance. The framework developed in this research could guide practitioners towards appropriate tools for applying circular building in their projects. However, in order to provide proper guidance, more research and development is needed with attention on user friendliness, prior knowledge and integral accessibility.

Third, from a researcher's perspective, the frameworks in Figures 2 and 3 are a first attempt to compare systemically the "supply and demand" in this field. This framework allows to further monitor the lack and oversupply of certain design support tools for circular building and guide researchers and 
developers further in their endeavours. Nevertheless, it also needs further refinement and validation. Concretely, possible research paths are:

1. A more elaborate study should be done to clarify how specific contextual aspects, such as the user profile and their expertise, affect the demands and aspirations on guidance in this transition to a circular building sector. Several stated needs in this study were not shared among all the interviewees such as the need for a circularity score or the classification of circular building materials and products;

2. It is recommended to develop the identified missing features and functionalities, albeit with feedback from the envisioned users. Following from the identified mismatches, this research advocates for a more participatory and practice-oriented approach when studying and developing design support tools for circular building;

3. Considering the mismatch between both, it might be interesting to investigate how the current research tracks on design support tools could become more in line with the needs of the building designers and advising engineers, although fundamental exploration must be possible too in particular about the impact of design tools on the design process in general. How can conceptual but scientifically based tools reach practice and influence the design process?

4. In this study, life cycle management and corresponding tools were not identified. Considering the close relation between design, circular business strategies (like PSS) and the life cycle management of assets [110]; therefore, the role of the product service system (PSS) approach and related tools should be further investigated. This might build on the changing role of the architectural designer in the transition to a circular economy, including a change from short-term involvement of the designer to a long-term engagement with the building [72].

Some of the shortfalls of this study include the focus on the region Flanders, which is a small region that has a specific construction sector culture and political landscape, and the small interview sample. However, given that Flanders can be considered as one of the forerunners in the transition towards a circular construction economy, makes the region and its ongoing initiatives a well-documented and instructive case for reflection and learning about the transition itself. The main limitation of the interview sample and the in-depth interviews is that generalizations about the results cannot be made because a small sample was chosen and random sampling methods were not used. These in-depth interviews, however, provide valuable information for a preliminary idea of what the needs are concerning design support tools for circular building and to be able to compare these needs with the available tools and research directions. Furthermore, this study focused on design support tools as a possible aid to provide guidance for the practitioners in the design process. Other tools and institutions can also be of significance as guidance, where the expertise of policy makers, researchers and consultants can be employed.

Through these insights and recommendations, this research wants to contribute to a much needed debate within the building sector supply chain to better understand and prioritise the key issues concerning supply and demand of design support tools for circular building practice and, consequently, supporting the construction sector in its transition to a circular, sustainable economy.

Author Contributions: The conceptualization, the outlining of the methodology, the original draft preparation and the making of the figures was performed by C.C.; For writing-review and editing, C.C. and W.G. were involved. The study was supervised by N.D.T. and W.G. All authors have read and agreed to the published version of the manuscript.

Funding: This research was funded by Fonds Wetenschappelijk Onderzoek (FWO), grant number 1S55518N.

Conflicts of Interest: The authors declare no conflict of interest.

\section{Appendix A. Interview Guide}

Face-to-face, semi-structured interviews were conducted to identify the specific needs of building designers and advising engineers who are trying to integrate circular principles in their practice and 
designs for design support tools (and their features) for circular building. The following questions served as an interview guide:

- First, the interviewer asked some general questions on the implementation of circularity in their design and on their use of tools: What does the term circularity mean to you? In what way have you tried to apply circularity in practice? Where did you gain knowledge about circularity? Do you know tools to design circular buildings? Do you use them? Why do you use them? Would you use them? What are the barriers to applying circular principles? What is the biggest difficulty you encounter when implementing circular principles in the projects?

- Second, per tool category, the interviewer asked more in-depth questions: Do you know such tools? Does it seem useful to you? Would you use it? Why or why not?

For example, for the category "Circularity Score", the following questions were asked: According to you, is a tool that measures the degree of circularity in a building useful? What criteria should be used to assess whether a product, component, element or building as a whole is circular or not?

\section{References}

1. Geissdoerfer, M.; Savaget, P.; Bocken, N.M.P.; Hultink, E.J. The Circular Economy-A new sustainability paradigm? J. Clean. Prod. 2017, 143, 757-768. [CrossRef]

2. Ghisellini, P.; Ripa, M.; Ulgiati, S. Exploring environmental and economic costs and benefits of a circular economy approach to the construction and demolition sector. A literature review. J. Clean. Prod. 2018, 178, 618-643. [CrossRef]

3. Kirchherr, J.; Reike, D.; Hekkert, M. Conceptualizing the circular economy: An analysis of 114 definitions. Resour. Conserv. Recycl. 2017, 127, 221-232. [CrossRef]

4. European Commission. EU Circular Economy Action Plan: A new Circular Economy Action Plan for a Cleaner and More Competitive Europe; European Union: Brussels, Belgium, 2020.

5. OVAM. Startverklaring Vlaanderen Circulair; OVAM: Mechelen, Belgium, 2016.

6. Demir, Z. Beleidsnota 2019-2024. Omgeving; Vlaams Parlement: Brussels, Belgium, 2019.

7. OVAM. Materiaalbewust Bouwen in Kringlopen: Preventieprogramma Duurzaam Materialenbeheer in de Bouwsector 2014-2020; OVAM: Mechelen, Belgium, 2013.

8. Ellen MacArthur Foundation. Case studies: Flanders Materials Programme. Available online: https: //www.ellenmacarthurfoundation.org/case-studies/belgium-flanders-materials-programme (accessed on 3 August 2020).

9. Silva, A.; Rosano, M.; Stocker, L.; Gorissen, L. From waste to sustainable materials management: Three case studies of the transition journey. Waste Manag. 2017, 61, 547-557. [CrossRef]

10. Paredis, E. A Winding Road: Transition Management, Policy Change and the Search for Sustainable Development. Ph.D. Thesis, Ghent University, Ghent, Belgium, 2012.

11. TOTEM: Environmental Profile of Building Elements. Available online: https://www.totem-building.be/ (accessed on 14 October 2019).

12. Vlaanderen Circulair Green Deal Circulair Bouwen. Available online: https://vlaanderen-circulair.be/nl/ onze-projecten/detail/green-deal-circulair-bouwen (accessed on 25 June 2020).

13. Open Call: Innovatieve Circulaire Economieprojecten. Available online: https://vlaanderen-circulair.be/nl/ aan-de-slag/open-call (accessed on 27 July 2020).

14. Hossain, M.U.; Ng, S.T. Critical consideration of buildings' environmental impact assessment towards adoption of circular economy: An analytical review. J. Clean. Prod. 2018, 205, 763-780. [CrossRef]

15. International Organization for Standardization (ISO). Sustainability in Buildings and Civil Engineering Works—Design for Disassembly and Adaptability_Principles, Requirements and Guidance; ISO 20887:2020; ISO: London, UK, 2020.

16. Bauwens, T.; Hekkert, M.; Kirchherr, J. Circular futures: What Will They Look Like? Ecol. Econ. 2020, 175, 106703. [CrossRef]

17. Geels, F.W.; Schot, J. Typology of sociotechnical transition pathways. Res. Policy 2007, 36, 399-417. [CrossRef] 
18. Debacker, W.; Manshoven, S.; Apelman, L.; Beurskens, P.; Biberkic, F.; Denis, F.; Durmisevic, E.; Dzubur, A.; Hansen, K.; Henrotay, C.; et al. Synthesis of the State of the Art: Key Barriers and Opportunities for Materials Passports and Reversible Building Design in the Current System; Buildings as Materials Banks: Brussels, Belgium, 2016; p. 103.

19. Vandenbroucke, M.; De Temmerman, N.; Paduart, A.; Debacker, W. Opportunities and obstacles of implementing transformable architecture. In Proceedings of the Int. Conf. on Sustainable Building, University of Minho, Guimarães, Portugal, 20 February 2013.

20. Weytjens, L.; Verdonck, E.; Verbeeck, G. Classification and Use of Design Tools: The Roles of Tools in the Architectural Design process. Des. Princ. Pract. Int. J. 2009, 3, 289-303. [CrossRef]

21. Adams, K.; Osmani, M.; Thorpe, T.; Thornback, J. Circular economy in construction: Current awareness, challenges and enablers. Waste Resour. Manag. 2017, 170, 15-24. [CrossRef]

22. Hart, J.; Adams, K.; Giesekam, J.; Tingley, D.D.; Pomponi, F. Barriers and drivers in a circular economy: The case of the built environment. Procedia CIRP 2019, 80, 619-624. [CrossRef]

23. Bocken, N.M.P.; de Pauw, I.; Bakker, C.; Grinten, B. van der Product design and business model strategies for a circular economy. J. Ind. Prod. Eng. 2016, 33, 308-320. [CrossRef]

24. Akinade, O.O.; Oyedele, L.O.; Bilal, M.; Ajayi, S.O.; Owolabi, H.A.; Alaka, H.A.; Bello, S.A. Waste minimisation through deconstruction: A BIM based Deconstructability Assessment Score (BIM-DAS). Resour. Conserv. Recycl. 2015, 105, 167-176. [CrossRef]

25. Osmani, M.; Glass, J.; Price, A.D.F. Architects' perspectives on construction waste reduction by design. Waste Manag. 2008, 28, 1147-1158. [CrossRef]

26. Taranic, I.; Behrens, A.; Topi, C. Understanding the Circular Economy in Europe, from Resource Efficiency to Sharing Platforms: The CEPS Framework; Social Science Research Network: Rochester, NY, USA, 2016.

27. Interviewing Experts; Bogner, A.; Littig, B.; Menz, W. (Eds.) Palgrave Macmillan: London, UK, 2009; ISBN 978-0-230-20680-9.

28. Lespagnard, M. Renovation of Residential Post-War Highrise: Understanding the dEsign Process and Impact of Reversible Design Tools and Strategies. Master's Thesis, Vrije Universiteit Brussel, Brussels, Belgium, 2019.

29. Geels, F.; Grin, J.; Loorbach, D.; Rotmans, J.; Schot, J.; Schot, J.; Grin, J. Transitions to Sustainable Development: New Directions in the Study of Long Term Transformative Change; Routledge: New York, NY, USA, 2011; ISBN 978-0-415-87675-9.

30. VUB Architectural Engineering. Building a Circular Economy. Design Qualities to Guide and Inspire Building Designers and Clients; Vrije Universiteit Brussel: Brussels, Belgium, 2019.

31. OVAM. 24 Ontwerprichtlijnen Veranderingsgericht Bouwen; OVAM: Mechelen, Belgium, 2016.

32. Circular Flanders. The Business Model Innovation Grid. Available online: https://www.vlaanderen-circulair. be/bmix/ (accessed on 22 October 2019).

33. Vandenbroucke, M. Bouwcatalogus Veranderingsgericht Bouwen; OVAM: Mechelen, Belgium, 2019.

34. Alba Concepts Building Circularity Index. Available online: https://albaconcepts.nl/building-circularityindex/ (accessed on 16 October 2019).

35. Cenergie C-CalC. Available online: https://www.cenergie.be/nl/diensten/advies/c-calc (accessed on 16 October 2019).

36. BAMB. Circular Building Assessment Prototype. Available online: https://www.bamb2020.eu/post/cbaprototype/ (accessed on 14 October 2019).

37. Ellen MacArthur Foundation. The Circular Design Guide. Available online: https://www.circulardesignguide. com/ (accessed on 20 March 2019).

38. Circular IQ Circular Transition Indicators. Available online: https://ctitool.com/ (accessed on 10 February 2020).

39. IDEAL\&CO. Explore BV Circularity Calculator. Available online: http://www.circularitycalculator.com/ (accessed on 14 October 2019).

40. EIT. RawMaterials Find a Circular Business Model that Fits. Available online: http://www.circulator.eu/ (accessed on 10 December 2019).

41. Ellen MacArthur Foundation. Circulytics-Measuring Circularity. Available online: https://www. ellenmacarthurfoundation.org/resources/apply/circulytics-measuring-circularity (accessed on 14 October 2019).

42. Remeha, B.V. Toolbox. Available online: https://home.et.utwente.nl/designtool/ 5d33e8a3cfb35737ec484429954f0ea98fed69d8/toolbox.html (accessed on 14 October 2019). 
43. OVAM. Bepaal de Milieu-Impact van uw Product en Maak het Verschil. Available online: http://www. ecolizer.be/ (accessed on 13 October 2019).

44. Sphera GaBi Circularity Toolkit-Circular Economy Software. Available online: http://www.gabi-software. com/international/software/gabi-software/gabi-circularity-toolkit/ (accessed on 11 February 2020).

45. Het Facilitair Bedrijf. GRO Gebruikershandleiding; Het Facilitair Bedrijf: Brussels, Belgium, 2019.

46. Superuse Studios NL Oogstkaart. Available online: https://www.oogstkaart.nl/ (accessed on 29 October 2019).

47. BRE Group IMPACT. Available online: https://www.bregroup.com/impact/ (accessed on 11 February 2020).

48. Insert. Available online: https://www.insert.nl/ (accessed on 29 October 2019).

49. Platform CB'23. Meten van Circulariteit; Platform CB'23: Delft, The Netherlands, 2020.

50. European Commission. Level(s): Building Sustainability Performance; European Commission: Brussels, Belgium, 2020.

51. Madaster Services Madaster Platform. Available online: https://www.madaster.com/nl/our-offer-2/MadasterPlatform (accessed on 11 October 2019).

52. World Business Council for Sustainable Development MarketplaceHUB. Available online: https:// marketplacehub.org/ (accessed on 29 October 2019).

53. Meex, E. Early Design Support for Material Related Environmental Impact Assessment of Dwellings. Ph.D. Thesis, UHasselt: Hasselt, Belgium, 2018.

54. NIBE Milieuclassificaties. Available online: https://www.nibe.info/nl (accessed on 12 October 2019).

55. Metabolism of Cities Online Material Flow Analysis Tool(OMAT). Available online: https://metabolismofcities. org/ (accessed on 18 February 2020).

56. Bionova Ltd OneCLick LCA. Available online: https://www.oneclicklca.com/ (accessed on 11 February 2020).

57. Rotor vzw Bouwen en Renoveren met Hergebruik. Available online: https://opalis.eu/nl (accessed on 29 October 2019).

58. openLCA. Available online: http://www.openlca.org/ (accessed on 13 November 2019).

59. Platform CB'23. Available online: https://platformcb23.nl/ (accessed on 14 November 2019).

60. Pixii Kennisplatform Energieneutraal Bouwen. Available online: https://pixii.be/ (accessed on 11 October 2019).

61. RIVM. LCIA: The ReCiPe Model. Available online: https://www.rivm.nl/en/life-cycle-assessment-lca/recipe (accessed on 11 February 2020).

62. Galle, W. Scenario Based Life Cycle Costing: An Enhanced Method for Evaluating the Financial Feasibility of Transformable Building. Ph.D. Thesis, Vrije Universiteit Brussel, Brussels, Belgium, 2016.

63. Pré Consultants, B.V. LCA Software for Fact-Based Sustainability. Available online: https://simapro.com/ (accessed on 10 February 2020).

64. TU Wien STAN. Available online: http://www.stan2web.net/ (accessed on 11 February 2020).

65. Totem. Available online: https://www.totem-building.be/ (accessed on 10 April 2020).

66. Werflink Werflink. Available online: https://www.werflink.com/nl-werflink.html (accessed on 29 October 2019).

67. Pomponi, F.; Moncaster, A. Circular economy for the built environment: A research framework. J. Clean. Prod. 2017, 143, 710-718. [CrossRef]

68. Haupt, M.; Zschokke, M. How can LCA support the circular economy? Int. J. Life Cycle Assess. 2017, 22, 832-837. [CrossRef]

69. Scheepens, A.E.; Vogtländer, J.G.; Brezet, J.C. Two life cycle assessment (LCA) based methods to analyse and design complex (regional) circular economy systems. Case: Making water tourism more sustainable. J. Clean. Prod. 2016, 114, 257-268. [CrossRef]

70. FAQ-Gebruik van de TOTEM-Tool. Available online: https://www.totem-building.be/pages/faq.xhtml (accessed on 10 April 2020).

71. How does Labelinfo Work? Available online: https://www.labelinfo.be/nl/hoe-werkt-labelinfo (accessed on 14 May 2020).

72. Galle, W.; Herthogs, P.; Vandervaeren, C.; De Temmerman, N. The Architect's Role in a Change-Oriented Construction Sector: A Belgian Perspective; Proceedings of Open Building for Resilient Cities: Los Angeles, CA, USA, 2018; pp. 69-75.

73. Thelen, D.; van Acoleyen, M.; Huurman, W.; Thomaes, T.; van Brunschot, C.; Edgerton, B.; Kubbinga, B. Scaling the Circular Built Environment: Pathways for Businesses and Government; World Business Council for Sustainable Development: Geneva, Switzerland, 2018. 
74. Laksov, K.B.; McGrath, C. Failure as a catalyst for learning: Towards deliberate reflection in academic development work. Int. J. Acad. Dev. 2020, 25, 1-4. [CrossRef]

75. Architects, interview by authors, Antwerp, Belgium. 3 September 2019.

76. Sustainability Engineer, interview by authors, Louvain-la-Neuve. 23 January 2019.

77. Jungic, V.; Creelman, D.; Bigelow, A.; Côté, E.; Harris, S.; Joordens, S.; Ostafichuk, P.; Riddell, J.; Toulouse, P.; Yoon, J.-S. Experiencing failure in the classroom and across the university. Int. J. Acad. Dev. 2020, 25, 31-42. [CrossRef]

78. Architect/Advisory Office, interview by authors, Antwerp, Belgium. 22 January 2019.

79. Architect, interview by authors, Brussels, Belgium. 4 November 2019.

80. Weytjens, L.; Verbeeck, G. Towards "architect-friendly" energy evaluation tools. In Proceedings of the 2010 Spring Simulation Multiconference, Society for Computer Simulation International, Orlando, FL, USA, 11-15 April 2010; pp. 1-8.

81. Becker-Olsen, K.; Potucek, S. Greenwashing. In Encyclopedia of Corporate Social Responsibility; Idowu, S.O., Capaldi, N., Zu, L., Gupta, A.D., Eds.; Springer: Berlin/Heidelberg, 2013; pp. 1318-1323, ISBN 978-3-642-28036-8.

82. Hobson, K.; Lynch, N. Diversifying and de-growing the circular economy: Radical social transformation in a resource-scarce world. Futures 2016, 82, 15-25. [CrossRef]

83. Gregson, N.; Crang, M.; Fuller, S.; Holmes, H. Interrogating the circular economy: The moral economy of resource recovery in the EU. Econ. Soc. 2015, 44, 218-243. [CrossRef]

84. Torelli, R.; Balluchi, F.; Lazzini, A. Greenwashing and environmental communication: Effects on stakeholders' perceptions. Bus. Strategy Environ. 2020, 29, 407-421. [CrossRef]

85. Testa, F.; Iovino, R.; Iraldo, F. The circular economy and consumer behaviour: The mediating role of information seeking in buying circular packaging. Bus. Strategy Environ. 2020. [CrossRef]

86. Hollberg, A.; Genova, G.; Habert, G. Evaluation of BIM-based LCA results for building design. Autom. Constr. 2020, 109, 102972. [CrossRef]

87. Akinade, O.O.; Oyedele, L.O.; Omoteso, K.; Ajayi, S.O.; Bilal, M.; Owolabi, H.A.; Alaka, H.A.; Ayris, L.; Henry Looney, J. BIM-based deconstruction tool: Towards essential functionalities. Int. J. Sustain. Built Environ. 2017, 6, 260-271. [CrossRef]

88. Mirza \& Nacey Research. The architectural profession in Europe; Architects' Council of Europe: West Sussek, UK, 2019.

89. Bueno, C.; Fabricio, M.M. Comparative analysis between a complete LCA study and results from a BIM-LCA plug-in. Autom. Constr. 2018, 90, 188-200. [CrossRef]

90. Santos, R.; Costa, A.A.; Silvestre, J.D.; Vandenbergh, T.; Pyl, L. BIM-based life cycle assessment and life cycle costing of an office building in Western Europe. Build. Environ. 2020, 169, 106568. [CrossRef]

91. Denis, F.; Vandervaeren, C.; De Temmerman, N. Using Network Analysis and BIM to Quantify the Impact of Design for Disassembly. Buildings 2018, 8, 113. [CrossRef]

92. Sanchez, B.; Rausch, C.; Haas, C.; Saari, R. A selective disassembly multi-objective optimization approach for adaptive reuse of building components. Resour. Conserv. Recycl. 2020, 154, 104605. [CrossRef]

93. van den Berg, M.C.; Durmisevic, E. BIM uses for reversible building design. In Proceedings of the Vital Cities and Reversible Buildings: Conference Proceedings; Sarajevo Green Design Foundation, Mostar, Bosnia and Herzegovina, 4-7 October 2017.

94. Heisel, F.; Rau-Oberhuber, S. Calculation and evaluation of circularity indicators for the built environment using the case studies of UMAR and Madaster. J. Clean. Prod. 2020, 243, 118482. [CrossRef]

95. Verberne, J. Building Circularity Indicators: An Approach for Measuring Circularity of a Building. Master's Thesis, Eindhoven University of Technology, Eindhoven, The Netherlands, 2016.

96. Nuñez-Cacho, P.; Górecki, J.; Molina-Moreno, V.; Corpas-Iglesias, F.A. What Gets Measured, Gets Done: Development of a Circular Economy Measurement Scale for Building Industry. Sustainability 2018, 10, 2340. [CrossRef]

97. Rockow, Z.R.; Ross, B.; Black, A.K. Review of methods for evaluating adaptability of buildings. Int. J. Build. Pathol. Adapt. 2019, 37, 273-287. [CrossRef]

98. Hertogs, P.; Debacker, W.; Tunçer, B.; De Temmerman, N.; Yves, D.W. Quantifying the Generality and Adaptability of Building Layouts using Weighted Graphs: The SAGA Method. Buildings 2019, 9, 20. [CrossRef] 
99. Geraedts, R. FLEX 4.0, A Practical Instrument to Assess the Adaptive Capacity of Buildings. Energy Procedia 2016, 96, 568-579. [CrossRef]

100. Conejos, S.; Langston, C.; Smith, J. AdaptSTAR model: A climate-friendly strategy to promote built environment sustainability. Habitat Int. 2013, 37, 95-103. [CrossRef]

101. Leising, E.; Quist, J.; Bocken, N. Circular Economy in the building sector: Three cases and a collaboration tool. J. Clean. Prod. 2018, 176, 976-989. [CrossRef]

102. Simons, C.; Galle, W.; De Temmerman, N. Proposal for a Guiding Toolbox for Circular Design in Renovation Projects. Master's Thesis, Vrije Universiteit Brussel, Brussel, Belgium, 2019.

103. van Stijn, A.; Gruis, V. Towards a circular built environment: An integral design tool for circular building components. Smart Sustain. Built Environ. 2019. [CrossRef]

104. Gehin, A.; Zwolinski, P.; Brissaud, D. A tool to implement sustainable end-of-life strategies in the product development phase. J. Clean. Prod. 2008, 16, 566-576. [CrossRef]

105. Bocken, N.; Short, S.; Rana, P.; Evans, S. A value mapping tool for sustainable business modelling. Corp. Gov. 2013, 13, 482-497. [CrossRef]

106. Virtanen, M.; Manskinen, K.; Eerola, S. Circular Material Library. An Innovative Tool to Design Circular Economy. Des. J. 2017, 20, S1611-S1619. [CrossRef]

107. Alamerew, Y.A.; Brissaud, D. Circular economy assessment tool for end of life product recovery strategies. J. Remanuf. 2019, 9, 169-185. [CrossRef]

108. Geldermans, R.J. Design for Change and Circularity-Accommodating Circular Material \& Product Flows in Construction. Energy Procedia 2016, 96, 301-311. [CrossRef]

109. Mahpour, A. Prioritizing barriers to adopt circular economy in construction and demolition waste management. Resour. Conserv. Recycl. 2018, 134, 216-227. [CrossRef]

110. Fargnoli, M.; Lleshaj, A.; Lombardi, M.; Sciarretta, N.; Di Gravio, G. A BIM-based PSS Approach for the Management of Maintenance Operations of Building Equipment. Buildings 2019, 9, 139. [CrossRef]

(C) 2020 by the authors. Licensee MDPI, Basel, Switzerland. This article is an open access article distributed under the terms and conditions of the Creative Commons Attribution (CC BY) license (http://creativecommons.org/licenses/by/4.0/). 